Research Article

\title{
Distribution Law of Mining Stress of the Gob-Side Entry Retaining in Deep Mining Thin Coal Seam
}

\author{
Tao Qin $\mathbb{D},{ }^{1,2}$ Kai Ren $\mathbb{D}^{1},{ }^{1}$ Chen Jiang $\mathbb{D},{ }^{1}$ Yanwei Duan $\mathbb{D}^{1},{ }^{1}$ Zhi Liu $\mathbb{D}^{1},{ }^{1}$ and Lei Wang $\mathbb{D}^{1}$ \\ ${ }^{1}$ Heilongjiang Ground Pressure and Gas Control in Deep Mining Key Lab, Heilongjiang University of Science and Technology, \\ Harbin 150022, China \\ ${ }^{2}$ School of Resources and Civil Engineering, Northeastern University, Shenyang 110819, China
}

Correspondence should be addressed to Kai Ren; 978011787@qq.com

Received 9 January 2021; Revised 2 March 2021; Accepted 10 March 2021; Published 26 March 2021

Academic Editor: Zhijie Zhu

Copyright $(2021$ Tao Qin et al. This is an open access article distributed under the Creative Commons Attribution License, which permits unrestricted use, distribution, and reproduction in any medium, provided the original work is properly cited.

\begin{abstract}
In order to explore the mining pressure development rule of gob-side entry retaining during deep thin coal seam mining, FLAC ${ }^{3 \mathrm{D}}$ numerical simulation is applied to analyze the stress distribution rule of gob-side entry retaining, observing the left third working face of $49^{\#}$ coal seam in No. 8 mining area of Xinxing Coal Mine as the research object. The results show that the working face stress field is asymmetrical which is caused by the reserved roadway and the over goaf. After roadway tunneling, features of obvious stress redistribution are formed. The vertical and horizontal stress in the coal seam develop a U-shaped distribution. The vertical stress in the roadway is less than that in the lower roadway, and the horizontal stress is half that in the lower roadway. The phenomenon of high stress "nucleation" appears and becomes more obvious in the process of working face advancing, and the nuclear body disappears after working face advanced to the boundary line. With the working surface advancing, the trend of horizontal stress of gob-side entry retaining decreases gradually and the vertical stress of gob-side entry retaining is less than the original rock stress. The research findings provide a basis for the supporting design of gob-side entry retaining in the deep thin coal seam and the stability control of surrounding rock.
\end{abstract}

\section{Introduction}

With the continuous process of coal mining, shallow coal resources are almost depleted, and mining is gradually accessing deep mining areas. Under the influence of high stress, the mechanical characteristics of surrounding rocks have changed substantially, and the occurrence of ore pressure induces more serious mine disasters [1]. China's thin coal seams are characterized by a diversified occurrence, large quantity, large distribution area, and large reserves. According to statistics, thin coal seams of the mining areas account for $84.2 \%$, and reserves are about 6 billion tons $[2,3]$. The gob-side entry retaining can maximize the recovery of resources and reduce the amount of drivage. The problem of surrounding rock control in thin coal mining the gob-side entry retaining brings severe challenges to coal mine safety mining; especially, the problem of stable gobside entry retaining in Qitaihe thin coal mining area, which has already entered the process of deep mining, is becoming increasingly prominent. It is of great significance for coal and rock stability control to explore the stress distribution of gob-side entry retaining in deep thin coal seam mining.

Scholars at home and abroad have done a lot of research on thin coal seam mining and the over goaf roadway retention, and they have achieved a series of successful results. According to the analysis of the plastic zone, stress distribution, supporting pressure, and deformation law of surrounding rock in thin coal seam mining by applying numerical simulation method, the finding obtained the ore pressure law of working face and proposed the supporting scheme [4-6]. Theoretical analysis is adopted to establish the mechanical deformation model of surrounding rock of thin coal seam under different geological conditions and to calculate the law of overburden movement and collapse and stress distribution [5-8]. Analyzing the support resistance, stress distribution, and surrounding rock deformation in the process of advancing the thin working face by on-site ore pressure monitoring method to evaluate whether the 
existing support system meets the requirements provides a reference to similar working face support design $[2,9,10]$. Application of gob-side entry retaining technology is employed to study stress distribution and support scheme in heading stope [11-14]. However, due to the essential differences in the mechanical properties of the shallow and deep rock mass, there are a few studies on the stress distribution characteristics and control measures of the gobside entry retaining in the thin coal seam. Besides, the existing studies have not explored the development law of the ore pressure of gob-side entry retaining in the deep thin coal seam.

Qitaihe mining area is one of the thin layers of oversize mine areas, with $0.86 \mathrm{~m}$ average thickness. At present, the average depth of three-level mining in the Xinxing Coal Mine is about $750 \mathrm{~m}$. In the mining process, there are many problems to solve, such as large deformation of surrounding rocks, difficult roadway maintenance, and poor safety. In order to ensure the recovery of resources and production continuity, mining is mainly carried out by keeping the gobside entry retaining [15]. Based on this, the author combines the actual situation of working face in $49^{\#}$ Xinxing Coal Mine, using FLAC $^{3 \mathrm{D}}$ numerical simulation of thin coal seam gob-side entry retaining in the mining process to analyze the working face stress distribution characteristics. The research results have theoretical guiding and reference significance for the surrounding rock control of deep thin coal seam gobside entry retaining in similar working conditions.

\section{Project Overview}

The working face adopts the method of longwall coal mining. There are three working faces on the third left of $49^{\#}$ coal seam in No. 8 mining area of Xinxing Coal Mine. The strike of the coal seam gradually changes from N60W to EW direction. The dip angle of the coal seam is generally between $7^{\circ}$ and $11^{\circ}$. The strike length is $565 \mathrm{~m}$, while the cutting length is $135 \mathrm{~m}$, and the inclined area is $7.63 \mathrm{~m}^{2}$. The thickness of the coal seam is $0.45 \sim 1.20 \mathrm{~m}$ and $0.65 \mathrm{~m}$ on average thickness. It belongs to the coal seam with a complex structure. The coal seam contains siltstone from one to six layers, and the interlayer thickness is generally $0.1 \sim 0.3 \mathrm{~m}$. The left two pieces are located in the upper part of the left three pieces and have been stopped, as shown in Figure 1.

\section{Numerical Analysis of the Development Law of Mine Pressure along Gob-Side Entry Retaining}

3.1. Simulation Scheme. Given that the left three working faces use gob-side entry retaining to mine in Xinxing Coal Mine, the stress distribution, with stopped area of the left three working faces is affected by the left two mines the over goaf and the remaining roadway. Therefore, in order to truly reflect the stress conditions of the left three working faces and the roadway, it needs to simulate the tunneling and mining conditions of the working face in the area around the left three. According to the idea of treating the over goaf by
FLAC $^{3 \mathrm{D}}$, the mechanical parameters of surrounding rocks are weak to simulate the left two goaves [16].

3.2. Model Establishment. On the basis of the borehole column chart and test data, the formation is simplified to address the needs of modeling. Therefore, fully considering the left three working faces of the over goaf, the stress distribution of roadway, and stope and its adjacent, the changes of model size for $450 \mathrm{~m} * 200 \mathrm{~m} * 96 \mathrm{~m}$, selecting the model left three floors at the bottom right corner to zero, the width of the mined-out area is $30 \mathrm{~m}$ and the groove is $5 \mathrm{~m}$, in view of the influence of stress, along the groove extend outward around $25 \mathrm{~m}$ for the border. The whole $3 \mathrm{D}$ model is divided into 11,187 units and 9,000 nodes. The model is shown in Figure 2. In order to analyze the stress distribution in the process of working face propulsion, single propulsion is applicable as the monitoring line, and the specific location is shown in Figure 3.

On account of the measured results of in situ stress in $49^{\#}$ coal seam, the maximum horizontal principal stress $\sigma_{\max }=31 \mathrm{MPa}$ and vertical principal stress $\sigma_{v}=15.89 \mathrm{MPa}$. With the increase of the buried depth, the constraint force on the $Z$ direction of the model presents an upward trend. Assuming that this point is at the floor of the coal seam roadway and combined with the excavation engineering plan, the average buried depth of the left three sections is $h=690 \mathrm{~m}$.

The horizontal principal stress of the model is

$$
\begin{aligned}
\sigma_{\text {max }} & =\gamma_{h} * h=31 \mathrm{MPa}, \\
\gamma_{h} & =3.1 e^{4} \mathrm{~N} / \mathrm{m}^{3}
\end{aligned}
$$

So,

$$
\begin{aligned}
& \sigma_{h 1}=\sigma_{h}-\gamma_{h} * h_{0}=19.79 \mathrm{MPa}, \\
& \sigma_{h 2}=\sigma_{h}+\gamma_{h} * h_{0}=25.37 \mathrm{MPa} .
\end{aligned}
$$

In light of the distribution of roof strata and rock density, the vertical stress on the roof surface of the model is

$\sigma_{v 1}=\sigma_{v}-\rho_{2} h_{2} g-\rho_{3} h_{3} g-\rho_{4} h_{4} g-\rho_{5} h_{5} g-\rho_{6} h_{6} g=11.77 \mathrm{MPa}$.

The front and rear boundaries of the model are fixed displacement constraints, and the left and right boundary conditions of the model are shown in Figure 4.

3.3. Calculated Parameters. Given the determination method of physical and mechanical properties of coal and rock, the coal and rock samples obtained in the field are processed and tested in the laboratory. Uniaxial compression deformation test, variable angle shear test, Brazilian splitting tensile test, and block density test are carried out, respectively. The experimental results are shown in Table 1, measured on the elastic modulus and shear modulus. The Mohr-Coulomb constitutive model is used for coal and rock mass. 


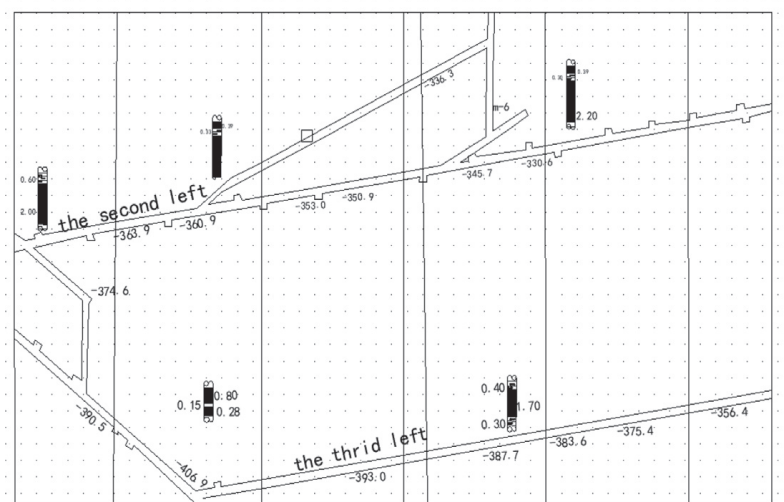

Figure 1: Roadway layout of the left third working face in the No. 8 mining area of 49 coal seams in Xinxing Coal Mine.

\section{Simulation Results and Analysis}

The stress concentration area is divided into vertical stress concentration area and horizontal stress concentration area. When excavation is carried out in the stratum, the surrounding rock stress is redistributed, continuously transferred to the interior, and the middle part of the working face presents the phenomenon of stress concentration. The vertical stress concentration occurs at the two sides of the surrounding rock, while the horizontal stress concentration occurs at the top and bottom of the surrounding rock. This paper aims at analyzing the stress distribution of the left three pieces of the gob-side entry retaining driving face and studying the stress distribution characteristics in the process of the gob-side entry retaining to driving face and driving face.

By analyzing the stress distribution of the roadway driving model on the left three sections of the gob-side entry retaining (see Figures 5 and 6), it can be seen that the vertical stress concentration area of the coal seam is near the roof of the coal seam, and the horizontal stress concentration area of the coal seam is at the two sides of the upper and lower roadway. Therefore, in the following concentrated-area study, the vertical stress concentration adapts the roof along the coal seam trending roadway as the main research object, while the horizontal stress concentration regards the central plane of the coal seam as the main research object.

Numerical simulation is carried out for the tunneling and stopping process of the left three blocks of the gob-side entry retaining; furthermore, it obtains the stress cloud chart and stress distribution curve. Due to roadway tunneling, the surrounding rock stress will be redistributed. In spite of the quite small influence of thin coal seam tunneling on stress redistribution, the stress concentration zone is still formed in the middle of the coal seam. The residual roadway and the over goaf have a certain impact on the stress distribution, resulting in stress asymmetry.

\subsection{Analysis of Stress Distribution in the Over Goaf Roadway}

4.1.1. Vertical Stress Concentration Area Distribution. Figure 7 shows that the vertical stress and the lower roadway stress in the middle of the coal seam are relatively large, and the maximum stress near the middle of the coal seam is 19.2 MPa. This is because, after the mining of the left two working faces, the remaining roadway in the left three working faces is adjacent to the over goaf, the surrounding rock stress has been released, and the pressure is low and uniform around the remaining roadway. The crossheading tunneling in the coal seam results in the redistribution of surrounding rock stress at the mining area boundary, the mine pressure transfers to the solid coal side, and the internal abutment pressure increases obviously. The farther the distance from the over goaf, the less the stress is affected by the over goaf, and the stress in stope increases gradually. Since the left second stope faces have been stopped and the roof strata collapse is basically stable, there is little influence on the left third stope roadway and the stope face, and the relatively large stress concentration is at the whole stope of the left third faces. The vertical stress, which is extracted from the monitoring line in Figure 8, is consistent with the trend of cloud Figure 7, showing a feature of high in the middle and low on both sides, and the roadway pressure in the retention roadway is less than the vertical stress in the lower roadway.

\subsubsection{Horizontal Stress Concentration Area Distribution.} It can be seen from Figure 9 that horizontal stress concentration occurs in the middle of the coal seam, with the maximum value reaching $17.8 \mathrm{MPa}$. The horizontal stress is small in the whole length of the remaining roadway, and the end surface stress of the lower roadway is relatively large. Due to the effect of the left second goaf, the horizontal stress of the upper roadway has a large influent range. It extends to the interior of the coal seam, greatly increasing the concentration degree of horizontal stress, resulting in a rapid increase of horizontal stress, and the stress is the largest in the middle position. After roadway excavation, the horizontal stress of roof and floor in roadway increases sharply within a certain range, which is not conducive to the stability of surrounding rock. The horizontal stress is very high in the middle of the coal seam, and the concentration coefficient is very high, which easily leads to roof caving and floor uplift, and may induce rock burst disaster. Figure 10 presents the horizontal stress on the monitoring line. The horizontal stress in the coal seam presents an obvious " $U$ " shaped distribution, with good symmetry on both sides, indicating the influence of the left second goaf area adjusted by the trough. The obvious difference between the two sides of the tunnel is mainly due to the impact of the left second goaf, which causes the horizontal pressure of the remaining roadway being half that of the lower side roadway.

\subsection{The Stress Concentration Area Distribution during Working Face Propulsion}

\subsubsection{Vertical Stress Concentration Area Distribution.} Figure 11 demonstrates that, with the working faces advancing, the maximum vertical stress of the roof of the coal seam firstly increases and then decreases, with the working face advancing to $200-300 \mathrm{~m}$, the maximum value is 


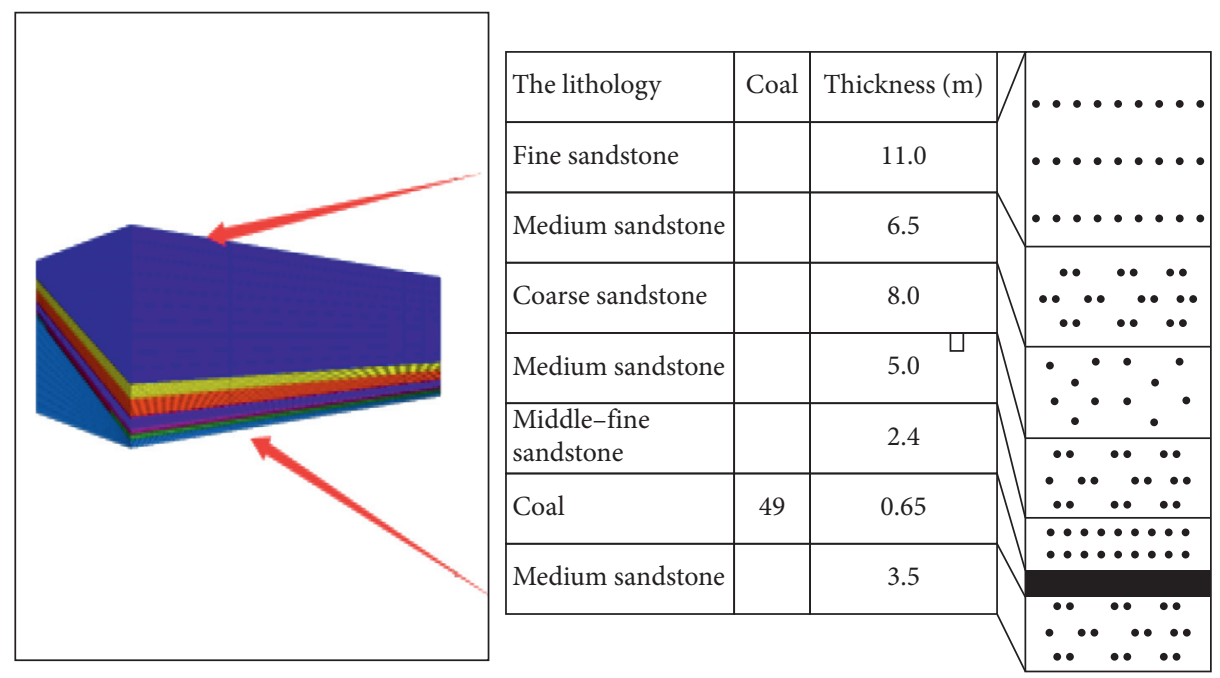

FIgURe 2: FLAC $^{3 \mathrm{D}}$ model of the third left mining face.

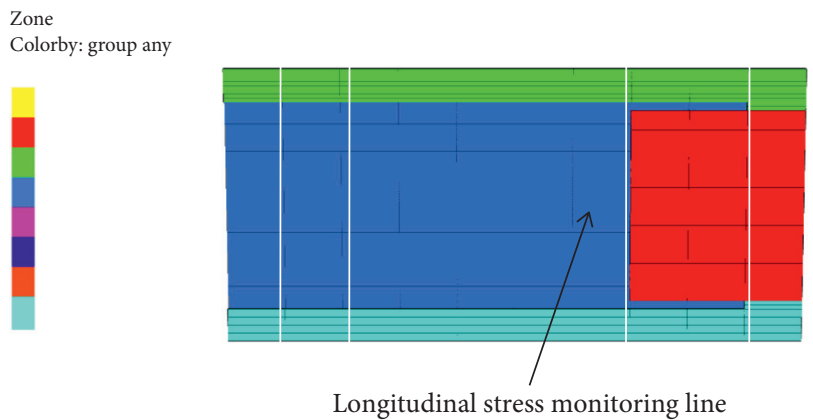

FIgure 3: Monitoring lines of the third left mining face.

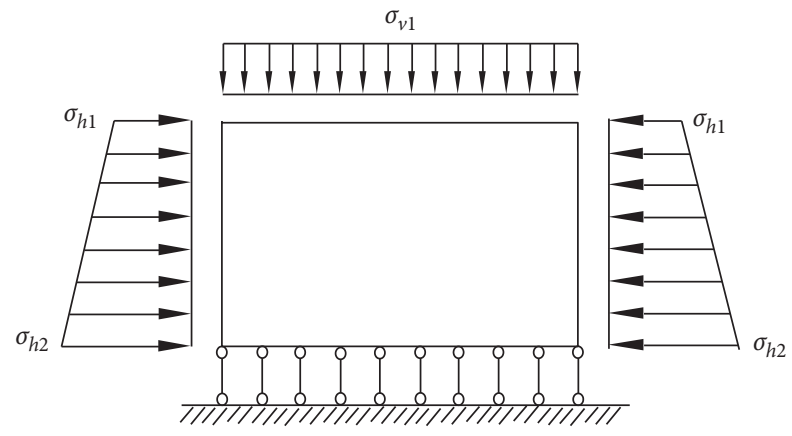

FIgURE 4: Boundary conditions of the model.

20.05 MPa, and the stress concentration coefficient is 1.20 . When the working face is advanced to $400 \mathrm{~m}$, the stress field is small and balanced in front of the working face. With the advance of the working face, the phenomenon of "nucleation" with high stress appearing on the working face becomes more growingly obvious, and the nuclear body disappeared after the working face is forward to the boundary line. Stress relief should be focused on the nuclear zone to prevent damage. Under the influence of the left second goaf, the average stress of the retaining roadway is less than the average stress of the lower roadway and less than the stress of the original rock, and the position of the upper and lower roadway is relatively stable, which is conducive to the stability of the roadway and the prevention and control of rock burst. Figure 12 illustrates the vertical stress change curve of the monitoring line in the process of working face propulsion, and the analysis shows that the stress concentration in the middle of the coal seam is obvious during the initial propulsion with the maximum value around $19 \mathrm{MPa}$. In pace with the continuous release of the propulsive stress, the stress concentration becomes weaker. When the working face is advanced to $400 \mathrm{~m}$, the vertical stress is around $17 \mathrm{MPa}$, which is close to the original rock stress. The inner part of the working face should pay attention to the initial pressure relief inside the coal body; especially, the stress nucleation area should be monitored.

\subsubsection{Horizontal Stress Concentration Area Distribution.}

The horizontal stress distribution is promoted to the left three working faces, as shown in Figure 13. It shows that the horizontal stress is mainly concentrated in the middle of the coal seam. As the working face advancing, the stress concentration becomes increasingly greater. The working face advances to $100 \mathrm{~m}$ and the maximum horizontal stress reaches 17.3 MPa. The working face advances to $200 \mathrm{~m}$, and the maximum horizontal stress reaches $17.8 \mathrm{MPa}$. The working face advances to $300 \mathrm{~m}$ and the maximum stress level reaches $17.9 \mathrm{MPa}$. The working face advances to $400 \mathrm{~m}$ and the horizontal maximum stress reaches 18.8 MPa. The horizontal stress of the upper and lower roadway is smaller than that of the original rock, the pressure of the gob-side entry retaining presents a trend of a gradual decline, and the floor pressure of the roadway is small. The pressure range and value of the upper roadway remain stable, and the pressure range of the upper roadway floor area gradually decreases, but the phenomenon of stress concentration appears obviously. Figure 14 shows the relationship between the monitoring line and the horizontal stress. According to the curve variation law, the horizontal stress in the middle reaches 
TABLE 1: Basically physical and mechanical parameters.

\begin{tabular}{|c|c|c|c|c|c|c|c|}
\hline & The lithology & $\begin{array}{c}\text { Volume modulus } \\
\text { (GPa) }\end{array}$ & $\begin{array}{l}\text { Shear modulus } \\
(\mathrm{GPa})\end{array}$ & $\begin{array}{l}\text { Cohesive force } \\
(\mathrm{MPa})\end{array}$ & $\begin{array}{c}\text { Tensile strength } \\
(\mathrm{MPa})\end{array}$ & $\begin{array}{c}\text { Within the angle of } \\
\text { wipe }\left({ }^{\circ}\right)\end{array}$ & $\begin{array}{l}\text { Density } \\
\left(\mathrm{kg} / \mathrm{m}^{3}\right)\end{array}$ \\
\hline 1 & $\begin{array}{l}\text { Pulverous } \\
\text { sandstone }\end{array}$ & 6.53 & 3.92 & 16 & 2.6 & 42 & 2690 \\
\hline 2 & Coal seam & 1.94 & 1.46 & 3 & 1.2 & 35 & 1400 \\
\hline 3 & $\begin{array}{l}\text { Pulverous } \\
\text { sandstone }\end{array}$ & 11.0 & 6.60 & 15 & 2.7 & 38 & 2697 \\
\hline 4 & $\begin{array}{l}\text { Medium } \\
\text { sandstone }\end{array}$ & 2.60 & 1.56 & 8 & 2.9 & 37 & 2688 \\
\hline 5 & Coarse sandstone & 3.53 & 2.12 & 10 & 1.7 & 42 & 2741 \\
\hline 6 & $\begin{array}{l}\text { Medium } \\
\text { sandstone }\end{array}$ & 2.60 & 1.56 & 13 & 2.9 & 48 & 2665 \\
\hline 7 & Fine sandstone & 10.49 & 6.30 & 15 & 2.6 & 55 & 2690 \\
\hline 8 & $\begin{array}{l}\text { Pulverous } \\
\text { sandstone }\end{array}$ & 6.53 & 3.92 & 16 & 2.6 & 42 & 2690 \\
\hline 9 & Goaf & 0.5 & 0.3 & 0.1 & 0.1 & 35 & 2600 \\
\hline
\end{tabular}

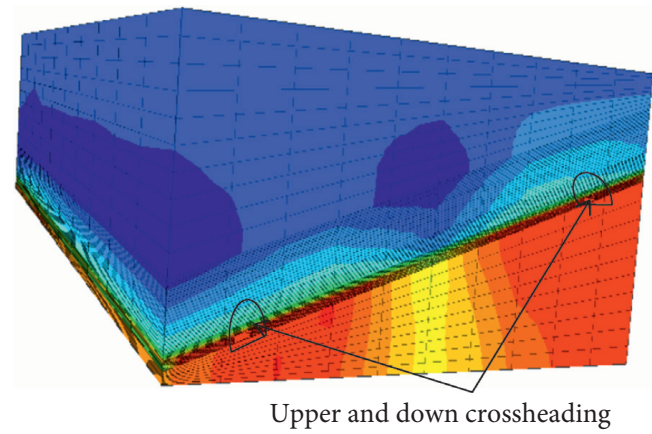

Figure 5: Model vertical stress cloud diagram.

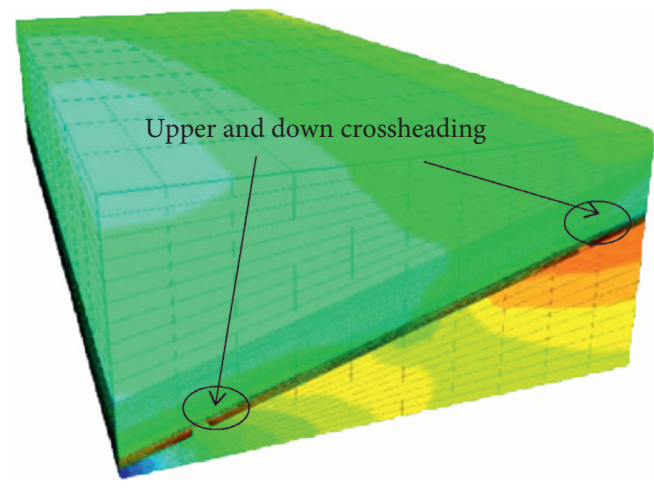

FIGURE 6: Model horizontal stress cloud diagram.

about $9 \mathrm{MPa}$ and presents a V-shaped distribution on both sides along the middle, and the pressure dropped in the gob-side entry retaining is greater than that of the other side roadway. The outside of the roadway presents the characteristics of two poles. Because the outside of the gob-side entry retaining is a goaf, the horizontal stress is less than $2 \mathrm{MPa}$. The stress outside the lower roadway increases sharply, reaching about $12 \mathrm{MPa}$. In summary, the pressure relief in the middle of the coal seam should be absorbed in ensuring the safety and stability in the mining process of the working face, and the floor of the lower roadway should be reinforced to prevent the occurrence of

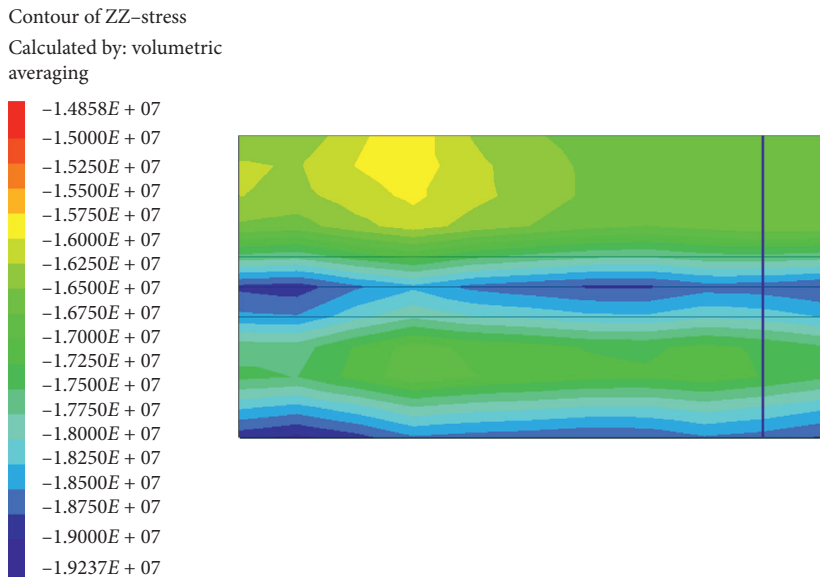

FIgURE 7: The vertical stress cloud diagram of the third left working face.

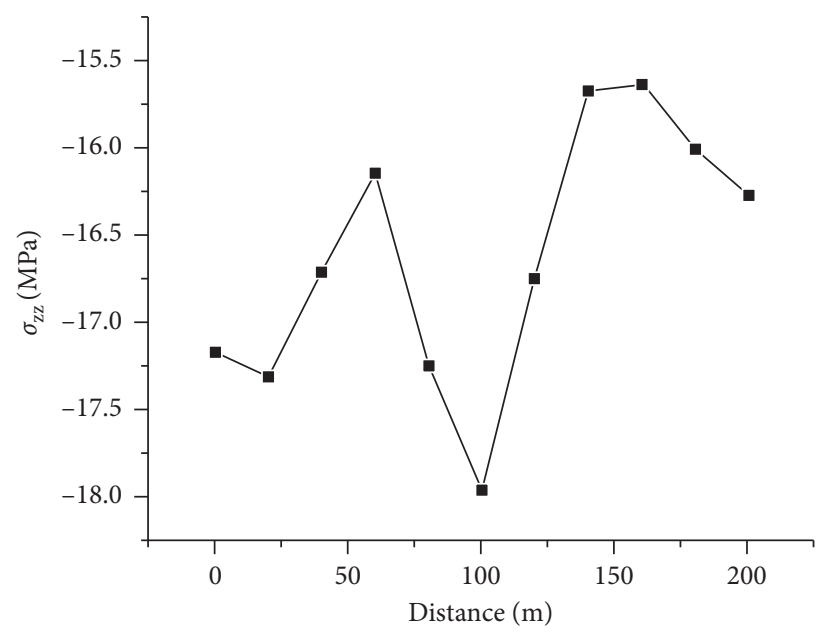

FIgURE 8: The vertical stress of monitoring points in the third left working face.

floor heave. The upper and lower sides of the roadway have low and stable pressure, which means safe and stable in the mining process. 
Contour of XX-stress

Calculated by: volumetric averaging

$-2.2120 E+05$
$-1.0000 E+06$
$-2.0000 E+06$
$-3.0000 E+06$
$-4.0000 E+06$
$-5.0000 E+06$
$-6.0000 E+06$
$-7.0000 E+06$
$-8.0000 E+06$
$-9.0000 E+06$
$-1.0000 E+07$
$-1.1000 E+07$
$-1.2000 E+07$
$-1.3000 E+07$
$-1.4000 E+07$
$-1.5000 E+07$
$-1.6000 E+07$
$-1.7000 E+07$
$-1.7790 E+07$

Figure 9: The horizontal stress cloud diagram of the third left working face.

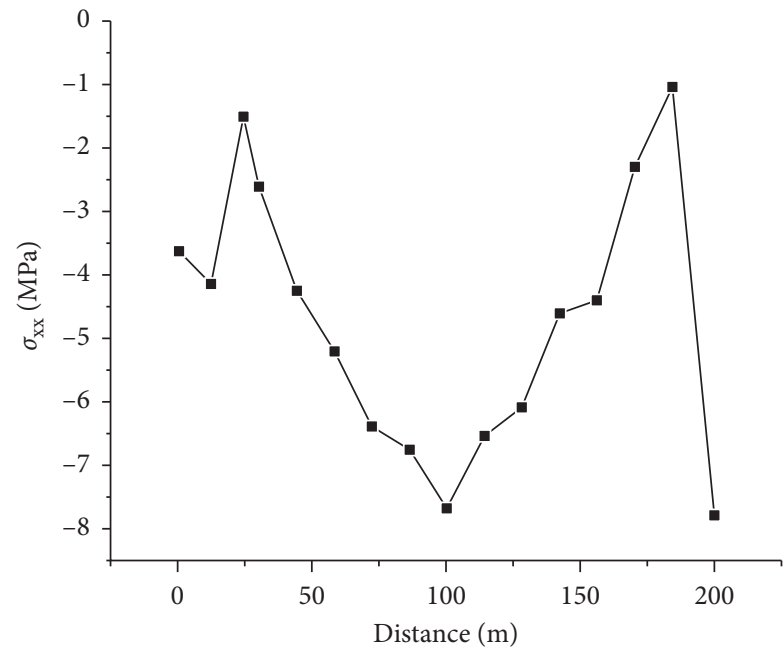

Figure 10: The horizontal stress of monitoring points in the third left working face.

Contour of ZZ-stress Calculated by: volumetric averaging

$-2.0000 E+05$

$-1.0000 E+06$

$-2.0000 E+06$

$-3.0000 E+06$

$-4.0000 E+06$

$-5.0000 E+06$

$-6.0000 E+06$

$-7.0000 E+06$

$-8.0000 E+06$

$-9.0000 E+06$

$-1.0000 E+07$

$-1.1000 E+07$

$-1.2000 E+07$

$-1.3000 E+07$

$-1.4000 E+07$

$-1.5000 E+07$

$-1.6000 E+07$

$-1.7000 E+07$

$-1.8000 E+07$

$-1.9000 E+07$

$-1.9980 E+07$
Contour of ZZ-stress Calculated by: volumetric averaging

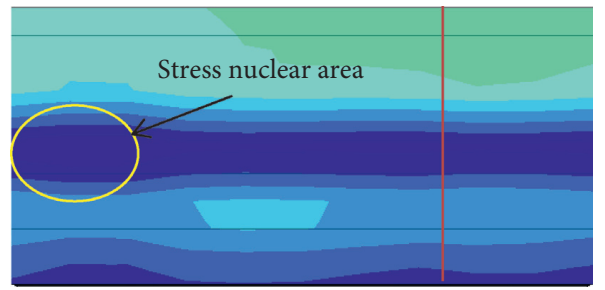

$-1.8632 E+05$

$-2.0000 E+06$

$-4.0000 E+06$
$-6.0000 E+06$

$-6.0000 E+06$

$-8.0000 E+06$

$-1.0000 E+07$

$-1.2000 E+07$

$-1.4000 E+07$

$-1.6000 E+07$

$-1.8000 E+07$

$-2.0000 E+07$

$-2.0036 E+07$

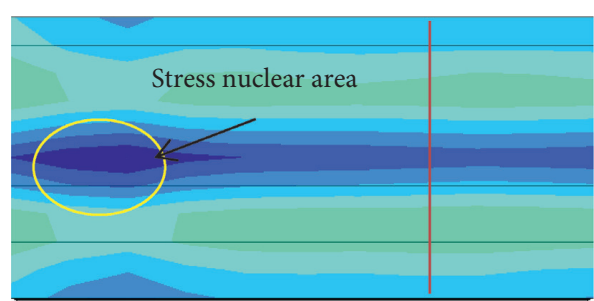

(a)

(b)

FIgURe 11: Continued. 


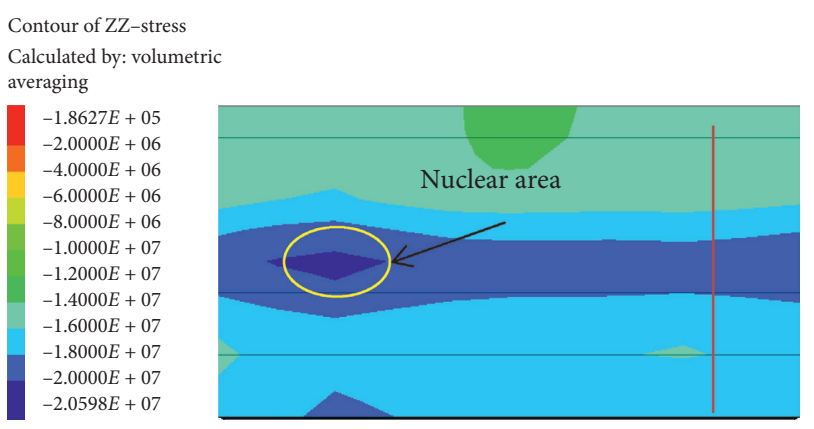

(c)
Contour of ZZ-stress

Calculated by: volumetric averaging

$$
\begin{aligned}
& -1.2959 E+05 \\
& -1.0000 E+06 \\
& -2.0000 E+06 \\
& -3.0000 E+06 \\
& -4.0000 E+06 \\
& -5.0000 E+06 \\
& -6.0000 E+06 \\
& -7.0000 E+06 \\
& -8.0000 E+06 \\
& -9.0000 E+06 \\
& -1.0000 E+07 \\
& -1.1000 E+07 \\
& -1.2000 E+07 \\
& -1.3000 E+07 \\
& -1.4000 E+07 \\
& -1.5000 E+07 \\
& -1.6000 E+07 \\
& -1.7000 E+07 \\
& -1.7469 E+07
\end{aligned}
$$

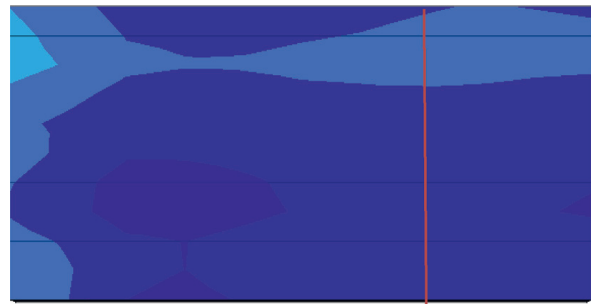

(d)

Figure 11: Advanced vertical stress cloud diagram of the third left working face. (a) The working face is advanced by $100 \mathrm{~m}$. (b) The working face is advanced by $200 \mathrm{~m}$. (c) The working face is advanced by $300 \mathrm{~m}$. (d) The working face is advanced by $400 \mathrm{~m}$.

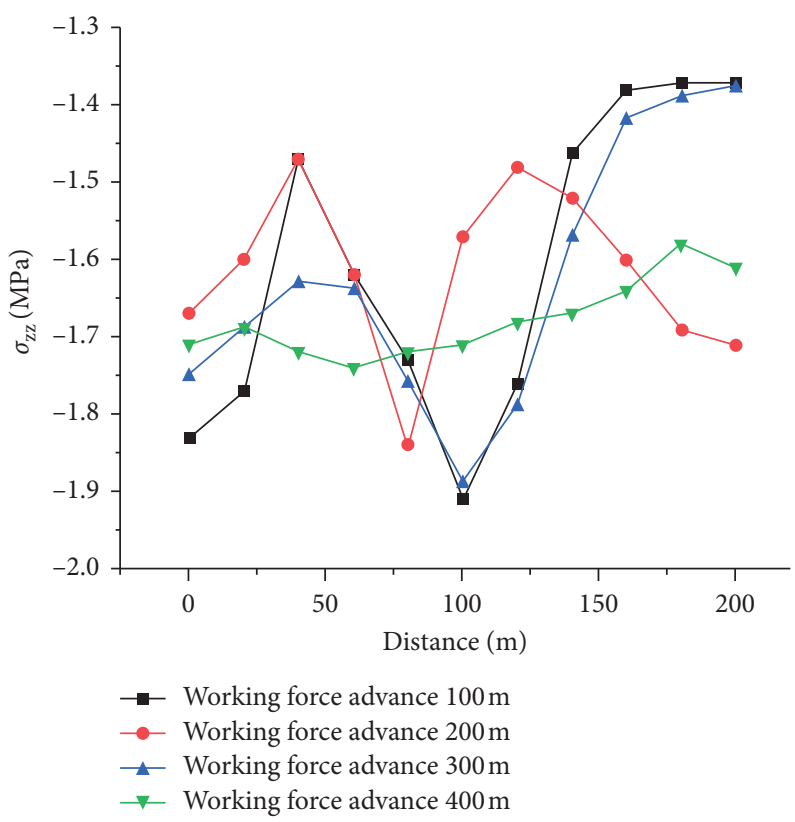

Figure 12: The vertical stress of monitoring points in the third left working face.

Contour of XX-stres Calculated by: volumetric averaging

$5.4918 E+04$ $0.0000 E+00$ $-1.0000 E+06$ $2.0000 E+06$ $-4.0000 E+06$ $-5.0000 E+06$ $-6.0000 E+06$ $7.0000 E+06$ $-8.0000 E+06$

-9.0000E + 06

$1.0000 E+07$

$-1.2000 E+07$

$-1.3000 E+07$

$1.4000 E+07$

$1.5000 E+07$

$1.6000 E+07$

$1.7000 E+07$

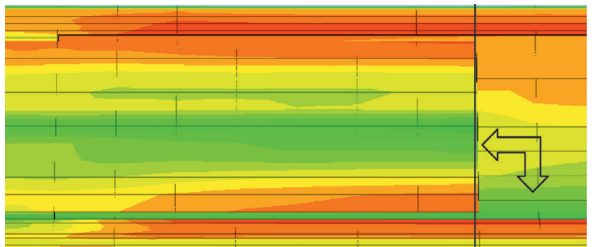

$y \uparrow_{z}^{x}$
Contour of XX-stress

Calculated by: volumetric

averaging
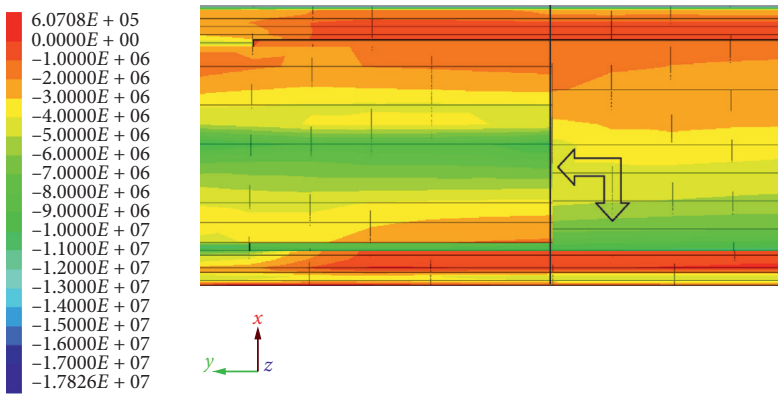

$y+\overbrace{z}^{x}$

(a)

Figure 13: Continued. 


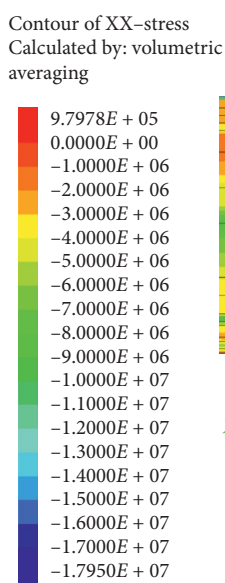

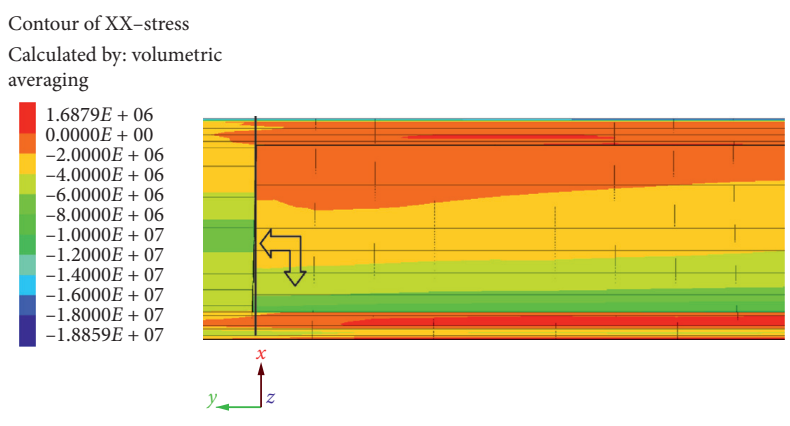

(d)

Figure 13: Advanced horizontal stress cloud diagram of the third left working face. (a) The working face is advanced by $100 \mathrm{~m}$. (b) The working face is advanced by $200 \mathrm{~m}$. (c) The working face is advanced by $300 \mathrm{~m}$. (d) The working face is advanced by $400 \mathrm{~m}$.

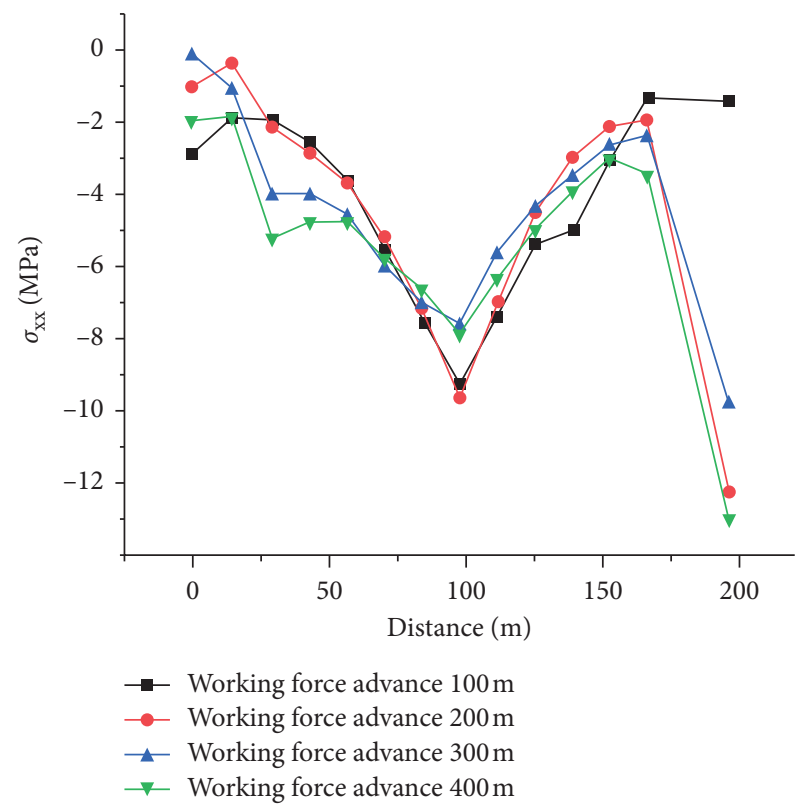

FIGURE 14: The horizontal stress of monitoring points in the third left working face.

\section{Conclusion}

By simulating the working face gob-side entry retaining of the left third working face of $49^{\#}$ coal seam in No. 8 mining area of Xinxing Coal Mine, the stress of remaining roadway is less than the vertical stress of lower roadway. The horizontal stress in the coal seam embodies an obvious " $U$ " shaped distribution, with good symmetry on both sides. The horizontal stress in the remaining roadway is half that in the lower roadway. The phenomenon of high stress "nucleation" appears and becomes more progressively obvious in the process of working face advancing, and the nuclear body disappears after working face advancing to the boundary line. The average vertical stress of the remaining roadway is less than the original rock stress, and the horizontal stress of the gob-side entry retaining presents a trend of gradual decrease. Corresponding pressure relief measures and actions should be taken to prevent the occurrence of disasters in the stress concentration area of deep thin coal seam during gob-side entry retaining driving and mining.

\section{Data Availability}

The data used to support the findings of this study are available from the corresponding author upon request (e-mail: 19140270@qq.com).

\section{Conflicts of Interest}

The authors declare that they have no conflicts of interest.

\section{Acknowledgments}

The research presented in this paper was supported jointly by the Central Government supports the Reform and Development Fund for Local Universities, the National Natural Science Foundation of China (51774122), and the National Key Research and Development Program (Grant no. 2016YFC0600901).

\section{References}

[1] M. He, H. Xie, S. Peng et al., "Research on rock mechanics in deep mining," Journal of Rock Mechanics and Engineering, vol. 24, no. 16, pp. 2803-2813, 2005.

[2] W. Guo, "Analysis on the rule of coal pressure in fully mechanized coal face of two hard and thin coal seams," Coal Science and Technology, vol. 44, no. 10, pp. 107-111, 2016.

[3] Z. Guo, Study on Highly Efficient Fully Mechanized Mining Technology of Extremely Thin Coal Seam in Huangsha Mine, China University of Mining and Technology, Beijing, China, 2013.

[4] S. Gu, Z. Sun, and S. Chen, "Numerical simulation analysis and support selection of steep thin coal seam roadway," Mine Pressure and Roof Management, vol. 79, no. 1, pp. 76-77, 2005. 
[5] Q. Sun, F. Ju, J. Zhang et al., "Analysis on the development law of mine pressure of double soft thin coal seam working face at roof and floor," Coal Science and Technology, vol. 42, no. 11, pp. 29-32, 2014.

[6] R. Zhu, K. Yang, and Z. Li, "Study on the occurrence law of ore pressure in fully mechanized coal face of deep well thin coal seam," Coal Technology, vol. 33, no. 5, pp. 159-162, 2014.

[7] T. Qin and J. Feng, "Law of overburden movement of mining face of inclined thin coal seam," Journal of Heilongjiang University of Science and Technology, vol. 25, no. 2, pp. 119123, 2015.

[8] Q. Li, Study on the Rule of Overburden Rock Movement in Shigetai Coal Mine with Thinner Shallow-Buried Coal Seam, Shandong University of Science and Technology, Qingdao, China, 2009.

[9] K. Shen, "Law of coal pressure development in stoping roadway of fully mechanized face of thin coal seam," Coal Mine Safety, vol. 49, no. 7, pp. 198-200+204, 2008.

[10] W. Guo, Y. Cheng, Y. Gao, Z. Chen, Z. Zhang, and C. Wang, "Structural characteristics of Datong coalfield and coal bearing boundary of Taiyuan Formation," Coal Geology and Exploration, vol. 43, no. 5, pp. 1-7, 2015.

[11] W. Wang, M. Gao, M. Wang et al., "Exploration on the deformation characteristics and stress distribution of deep buried roadway along the over goaf," Journal of Rock Mechanics and Engineering, vol. 38, no. S1, pp. 2955-2963, 2019.

[12] G. Hou, T. Hu, Z. Li et al., "Effect of cutting top height on the stability of the over goaf retaining roadway along side support," Journal of Mining and Safety Engineering, vol. 36, no. 5, pp. 924-931, 2019.

[13] Y. Ren, Study on Stress Distribution and Deformation Characteristics of Backfill beside the over Goaf Retaining Roadway and Optimization of Roof Precrack Angle, Taiyuan University of Technology, Taiyuan, China, 2019.

[14] P. Wang, Research on the Over Goaf Retention Technology of no. 6 Coal Seam Near the Xiangsheng Coal Mine, Taiyuan University of Technology, Taiyuan, China, 2019.

[15] W. Peng, "Research on the Over Goaf Retention Technology of No. 6 Coal Seam Near The Xiangsheng Coal Mine," Taiyuan University of Technology, Taiyuan, China, 2019.

[16] Z. Liu, Q. Gao, X. Hua et al., "Aging characteristics of surrounding rock control for the over goaf roadway excavation," Journal of Mining and Safety Engineering, vol. 26, no. 4, pp. 465-469, 2009. 